\title{
USE OF HORMONAL AND ULTRASONOGRAPHIC EXAMINATIONS TO DETERMINE THE FETAL NUMBER IN BULGARIAN LOCAL GOATS
}

\author{
Manol Karadaev ${ }^{1}$, Ivan Fasulkov ${ }^{1}$, Radina Vasileva², Nasko Vasilev ${ }^{1}$ \\ ${ }^{1}$ Department of Obstetrics, Reproduction and Reproductive Disorders, \\ Faculty of Veterinary Medicine, Trakia University, 6015 Stara Zagora, Bulgaria \\ ${ }^{2}$ Student of Veterinary Medicine, Faculty of Veterinary Medicine, Trakia University, \\ 6015 Stara Zagora, Bulgaria
}

Received 2 March 2018; Received in revised form 22 June 2018; Accepted 22 August 2018

\begin{abstract}
The purpose of the present study was to determine the fetal number in goats by using hormonal and ultrasonographic examinations. The experiments were conducted with 106 clinically healthy Bulgarian local goats, 1.5 to 7 years of age, weighing $35-52 \mathrm{~kg}$. Hormonal examinations were performed on 24 goats. Serum progesterone concentrations were measured during a 7 days interval, between 21-63 day of pregnancy, and during a 14 days interval until the $133^{\text {rd }}$ day of pregnancy. Ultrasound examinations were performed on 82 goats with a multi-frequency linear transducer (5.0-12.0 MHz). All animals were studied once during an interval of 7 days transrectally (21-28 day, 29-35 day, 36-42 day) and transabdominally (43-49 day, 50-56 day, 57-63 day), respectively. The accuracy of determining the number of singleton and multiple pregnancies by hormonal analysis were $51 \%, 58 \%, 69 \%$ and $47 \%, 52 \%, 62 \%$, respectively. The accuracy of ultrasonography to determine the number of fetuses is highest in singletons $76.18 \%$, followed by twins $72.56 \%$ and the lowest in triplets and more fetuses $21.43 \%$. Highest accuracy, sensitivity and positive predictive diagnosis were established in the period $43-49$ day of pregnancy $(\mathrm{P}<0.05)$. The obtained results show that the most appropriate period is between 42 and 49 day of pregnancy for determination of the fetal number in Bulgarian local goats using ultrasonography.
\end{abstract}

Key words: goats, ultrasonography, fetal number, progesterone

\section{INTRODUCTION}

Fetal number determination is an important step of reproduction management in goats. The classification of herds based on fetal numbers would result in a different technological regimen, feed cost and reproductive management optimization (1, 2). The determination of fetal numbers via blood progesterone concentrations has been reported in sheep (3) and goats (4).

Ultrasonography offers clear advantages for real-time determination of fetal numbers compared

Corresponding author: Assist. Prof. Ivan Fasulkov, $\mathrm{PhD}$

E-mail address: i.fasulkov@gmail.com

Present address: Department of Obstetrics, Reproduction and

Reproductive Disorders, Faculty of Veterinary Medicine, Trakia

University, 6015 Stara Zagora, Bulgaria

Phone: +35942699515

Copyright: (C) 2018 Karadaev M. This is an open-access article published under the terms of the Creative Commons Attribution License which permits unrestricted use, distribution, and reproduction in any medium, provided the original author and source are credited.

Competing Interests: The authors have declared that no competing interests exist.

Available Online First: 18 November 2018

Published on: 15 March 2019

https://doi.org/10.2478/macvetrev-2018-0029 to other techniques (5). It is the most commonly used method as it allows for a simultaneous determination of the number, vitality and gestational age of fetuses. For this purpose, precise criteria and optimum time of the exam should be chosen depending on the equipment, age and breed of animals $(6,7,8,9)$.

The number of embryos/fetuses could be identified until the $100^{\text {th }}$ gestational day, but the period with ultimate accuracy and visualization of the uterus without overlapping of fetuses is between the $40^{\text {th }}$ and the $70^{\text {th }}$ gestational day $(5,10,11,12)$. To minimize false positive and negative diagnoses, some authors recommend preliminary fasting of animals, and lifting of the abdominal wall during the exam $(12,13)$.

Using a transabdominal approach with probe frequency of $5 \mathrm{MHz}$ in Alpine does, researchers differentiated single, twin and triplet pregnancies with precision of $44 \%, 73 \%$ and $67 \%$ respectively during the $5^{\text {th }}$ gestational week (1). Suguna et al. (8) reported that the distinction between single 
and twin pregnancy was possible at the earliest by the $35^{\text {th }}$ gestational day via transrectal approach and by the $42^{\text {nd }}$ day with the transabdominal approach. The authors suggested that the period between the $5^{\text {th }}$ and $7^{\text {th }}$ gestational weeks was the most appropriate for differentiation between single and twin pregnancy in local goat crosses. Others determined fetal numbers in Saanen goats using the transvaginal approach with a 5-7.5 $\mathrm{MHz}$ probe and demonstrated $17 \%$ accuracy during the $3^{\text {rd }}$ week and $60 \%$ during the $8^{\text {th }}$ week of gestation, also confirming that the transvaginal approach was not the best for determination of multiple pregnancy in goats (14).

According to numerous researchers, the type of pregnancy (single or multiple) influences substantially the precision of the method, so it is difficult to distinguish among twins, triplets and quadruplets at each stage of the gestation in both goats and sheep $(3,15,16)$. Increased locomotor activity of the embryo impedes the differentiation between twin and multiple pregnancies especially until the $40^{\text {th }}$ gestational day. Counting twice an embryo is another error, which could be avoided by $\mathrm{B} / \mathrm{B}$ scan regimen to differentiate the fetuses (9), and the operator should scan slowly the area from left to the right at the same level to localize the uterus cross-section. Then the direction of scanning should be perpendicular to the previous one to include successively the entire area (12).

Although many available ultrasonographic studies of fetal counting were performed in goat breeds in different regions of the world, investigations on the effect of pregnancy type, breed, ultrasonography method and equipment in local goats have not been performed yet. For these reasons, the purpose of the present study was to determine the fetal number in Bulgarian local goats by use of hormonal and ultrasonographic examinations.

\section{MATERIAL AND METHODS}

\section{Experimental animals}

The experiments were performed with 106 Bulgarian local goats with an average body weight $35-52$ (mean 43.5) kg, 1.5 to 7 (mean 4.25) years of age. Some of animals were reared in the Experimental Farm of the Trakia University, Stara Zagora $(n=24)$, and the other goats were from different private farms in Losenets, Sliven region $(n=54)$ and Marinka, Burgas region $(n=28)$. The goats were both stall-fed and pasture-grazed and also received additionally concentrate. Roughage, drinking water and slat licks were offered ad libitum. All goats were given antiparasitic and immunoprophylactic treatments before the experiments. The experiments were approved by the Animal Ethics Committee to the Faculty of Veterinary Medicine, Trakia University - Stara Zagora, in compliance to Ordinance No. 20 of the Ministry of Agriculture and Food from 1 November 2012.

\section{Determination of fetal numbers by serum progesterone analysis}

For this purpose, 24 pregnant animals were used. Serum progesterone levels were assayed between 21 - 63 days of gestation at 7-day intervals and until the $133^{\text {rd }}$ day at 14-day intervals using a commercial ELISA kit and ELISA Huma Reader (HUMAN, Germany). After parturition, the animals were divided into 3 groups depending on the number of offspring (one, two or more) and the gestational stage, accounting also for abortions and stillborn fetuses. The mean serum progesterone concentrations in the different groups were calculated and analyzed.

\section{Determination of fetal numbers by two- dimensional ultrasonography}

Ultrasound scans were performed on 82 goats. All animals were examined once at 7-day intervals using the transrectal approach between gestational days 21-28, 29-35, 36-42 and by the transabdominal approach between 43-49, 50-56, and 57-63 days of pregnancy. For this purpose, goats were fixed in a standing position by an assistant. Fetal numbers were determined after visualization of an embryo/ fetus with or without cardiac activity in the anechoic uterine lumen section, using the B and B-B working modes of the equipment.

\section{Serum progesterone assay}

Serum samples for hormonal analysis were collected from the vena jugularis externa after previous fixation. Disposable $18 \mathrm{G}$ needles and closed-system serum tubes (with pearls) 16x75 $\mathrm{mm}, 10 \mathrm{ml}$ (Biosigma, Italy) were used to obtain $5 \mathrm{ml}$ from each animal. After being transported to the lab, blood was centrifuged at $3000 \mathrm{~g}$ for $15 \mathrm{~min}$. Enzyme activity was detected at a wavelength of $450 \mathrm{~nm}$ on a Huma Reader (HUMAN, Germany). Optic densities of samples were read as progesterone concentrations $(\mathrm{ng} / \mathrm{ml})$ against a standard curve. 
Fetal number in Bulgarian goats: Hormonal and ultrasonographic study

\section{Ultrasonography}

Ultrasonography was done with a SonoScape A5v (SonoScape, China) ultrasound machine equipped with linear multifrequency linear transducer (5.0-12.0 $\mathrm{MHz})$ after preliminary application of contact gel (Eco-Ultra gel, Milano, Italy).

Hormonal and ultrasonographic determination of fetal numbers

The number of fetuses (embryos) was determined as per Gearhart et al. (17). For a more convenient counting and avoiding errors, the B-B working mode of the equipment was used. After the kidding data became available, the true positive (a), false positive (b), true negative (c), false negative (d) diagnoses were determined, as well as positive (PPV) and negative (NPV) predictive values. The accuracy specificity and sensitivity of the method, PPV and NPV were calculated (18).

\section{Statistical analysis}

The data was analysed using the statistical software StatSoft (Statistica 7, Microsoft Corp. 1984-2000 Inc.) by means of ANOVA, LSD test for multiple comparisons, non-parametric comparisons of proportions using the $t$-criterion of Student. The analysis of variance determined the statistically significant effects of the studied factors. Results were presented as mean \pm standard deviation (SD), relative share $(\%)$ and levels of significance. The level of significance was set at $\mathrm{P}<0.05$.

\section{RESULTS}

The animals were classified according to the number of offspring at parturition. Then they were separated into two principal groups. The first group comprises of goats that gave birth to one kid (single pregnancy, $n=8$ ) and in the second - those giving birth to two or more kids (multiple pregnancy, $\mathrm{n}=16$ ). Mean serum progesterone concentrations (Fig. 1) in goats with multiple pregnancies were $13.88 \pm 3.28 \mathrm{ng} / \mathrm{ml}$ on day $21 \mathrm{vs} 9.92 \pm 4.91 \mathrm{ng} / \mathrm{ml}$ in those with single pregnancy. By the $63 \mathrm{rd}$ gestational day, the attained levels were $15.73 \pm 5.42 \mathrm{ng} / \mathrm{ml}$ and $11.58 \pm 4.67 \mathrm{ng} / \mathrm{ml}$, respectively. There were statistically significant differences between both groups of goats on gestational days $21(\mathrm{P}<0.01)$ and $63(\mathrm{P}<0.05)$ depending on the pregnancy type.

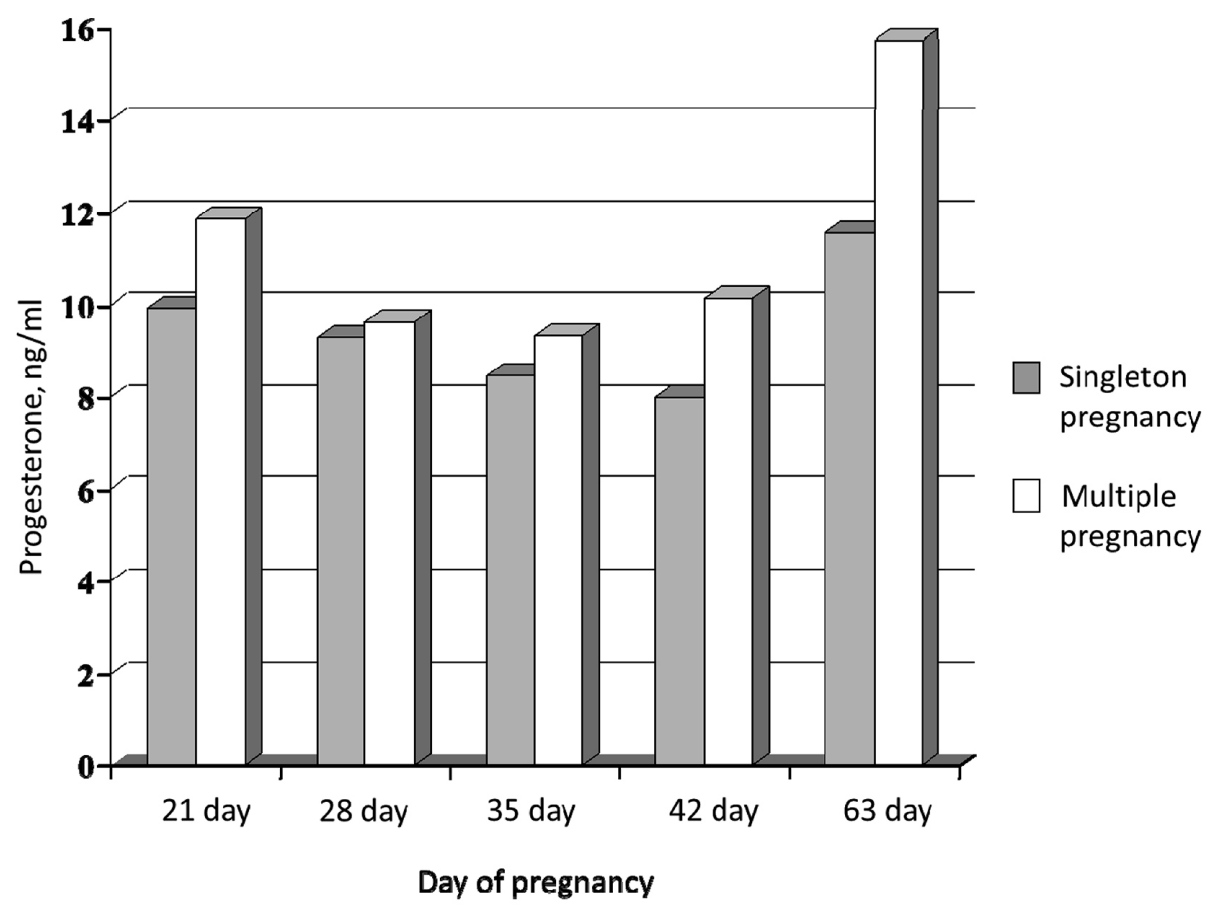

Figure 1. The mean serum progesterone concentrations $(\mathrm{ng} / \mathrm{ml})$ in single and multiple pregnancies 
Table 1. Average, indicative and non-indicative serum progesterone concentrations (ng/ml) in single and multiple pregnancies

\begin{tabular}{llll}
\hline Parameters & 21 day & 42 day & 63 day \\
\hline Single pregnancy & $9.92 \pm 2.91$ & $7.99 \pm 3.97$ & $11.58 \pm 4.67$ \\
Multiple pregnancy & $13.88 \pm 2.28^{*}$ & $10.15 \pm 6.79$ & $15.73 \pm 5.42^{* *}$ \\
Concentrations indicating single pregnancy & $<7.1$ & $<6.2$ & $<6.9$ \\
Non-indicative concentrations & $8-12$ & $7-11$ & $7-16$ \\
Concentrations indicating multiple pregnancy & $>12.8$ & $>11.1$ & $>16.2$ \\
\hline
\end{tabular}

Statistically significant difference compared to singleton and twin pregnancies at $* \mathrm{P}<0.01, * * \mathrm{P}<0.05$

Indicative progesterone concentrations for goats with single pregnancy during the different periods were $<7.1 \mathrm{ng} / \mathrm{ml},<6.2 \mathrm{ng} / \mathrm{ml},<6.9 \mathrm{ng} / \mathrm{ml}$, while for multiple pregnancies: $>12.8 \mathrm{ng} / \mathrm{ml},>11.1 \mathrm{ng} / \mathrm{ml}$, $>16.2 \mathrm{ng} / \mathrm{ml}$ (Table 1). The accuracy of fetal number determination in the different periods was $51 \%, 58 \%, 69 \%$ and $47 \%, 52 \%, 62 \%$ for single and multiple pregnancies, respectively.

Fetal numbers were determined in 82 goats at a different gestational age. They were divided into 3 groups - with single pregnancy $(n=21)$, with twin pregnancy $(n=47)$ and carrying triplets or more $(\mathrm{n}=14)$. After the parturition, 16 out of 21 diagnoses were confirmed and 5 were false. With regards to twin pregnant goats detected ultrasonographically, 34 diagnoses were confirmed and 13 of them were false. In the group with 3 or more fetuses, 3 true and 11 false diagnoses were detected. In summary, 53 of all 82 diagnoses were confirmed after the parturition and 29 of them were found erroneous.

The accuracy of ultrasonography with respect to fetal number was the highest in single pregnancies (76.18\%), followed by twin $(72.56 \%)$ and the lowest in multiple pregnancies $-21.43 \%$ (Table 2 ).

Table 2. Accuracy of ultrasonographic fetal counting results depending on pregnancy type

\begin{tabular}{lll}
\hline $\begin{array}{l}\text { Single pregnancy } \\
\mathbf{n}=\mathbf{2 1}\end{array}$ & $\begin{array}{l}\text { Twin pregnancy } \\
\mathbf{n}=\mathbf{4 7}\end{array}$ & $\begin{array}{l}\text { Multiple pregnancy } \\
\mathbf{n}=\mathbf{1 4}\end{array}$ \\
\hline $76.18 \%^{\mathrm{a}}$ & $72.56 \%^{\mathrm{a}}$ & $21.43 \%^{\mathrm{b}}$ \\
\hline
\end{tabular}

${ }^{a}$ values with different superscripts differ at $\mathrm{P}<0.001$

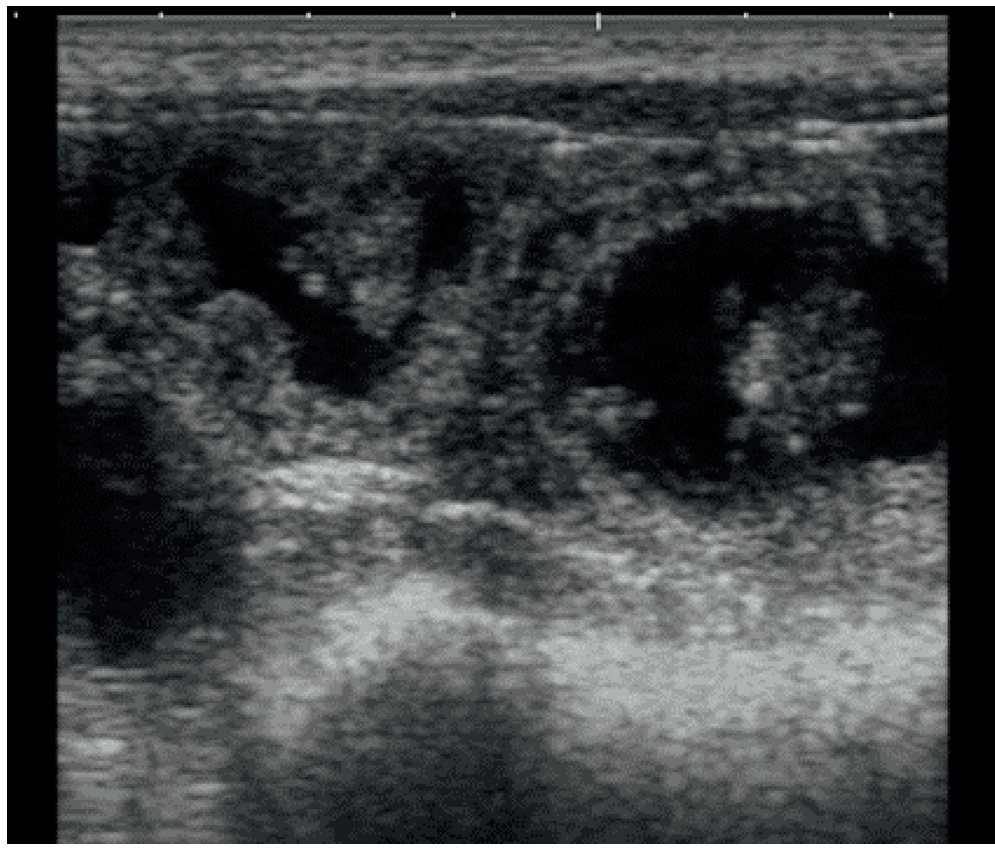

Figure 2. Ultrasonographic image of twin fetuses at $28^{\text {th }}$ day of pregnancy 


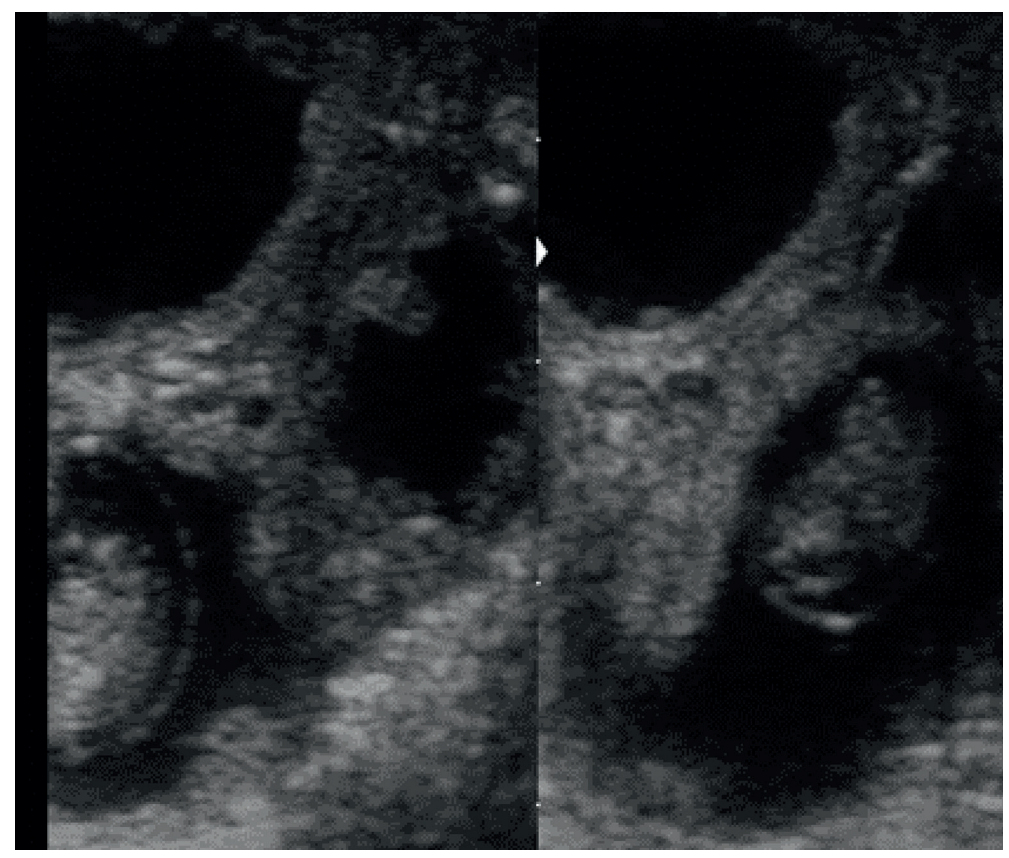

Figure 3. Ultrasonographic image of twin fetuses at $35^{\text {th }}$ day of pregnancy (B-B mode)

Within the 21-28 gestational days (Fig. 2), the accuracy of ultrasonography for fetal number determination was $51.16 \%$ with sensitivity of $61.53 \%$. Between the $29-35$ (Fig. 3) and 36-42 days of pregnancies, the accuracy and sensitivity of the method were higher. During the next gestational periods, a substantial increase in accuracy for transrectal fetal number determination was established. The highest accuracy of $87.50 \%$, sensitivity of $94.12 \%$ and positive predictive value of $76.19 \%$ were found out between the $43^{\text {rd }}$ and $49^{\text {th }}$ gestational day using the transabdominal approach (Table 3). It was considerably higher than that registered during the subsequent periods $(\mathrm{P}<0.05)$, and showed a tendency towards reduction as the gestational age advanced.

Table 3. The accuracy, sensitivity, specificity and prognostic value of ultrasonographic fetal counting results depending on gestational age and sonographic approach

\begin{tabular}{|c|c|c|c|c|c|c|}
\hline \multicolumn{7}{|c|}{ Day of examinations and ultrasonographic outcomes } \\
\hline \multicolumn{2}{|c|}{ Approach } & \multicolumn{2}{|c|}{ Transrectal } & \multicolumn{3}{|c|}{ Transabdominal } \\
\hline Period & 21-28 & 29-35 & $36-42$ & 43-49 & $50-56$ & $57-63$ \\
\hline Number & $\mathbf{n}=\mathbf{2 4}$ & $\mathbf{n}=\mathbf{2 4}$ & $\mathbf{n}=\mathbf{2 4}$ & $\mathrm{n}=\mathbf{2 4}$ & $\mathbf{n}=\mathbf{2 4}$ & $\mathbf{n}=\mathbf{2 4}$ \\
\hline $\mathbf{a}$ & 8 & 9 & 10 & 16 & 13 & 10 \\
\hline b & 6 & 5 & 5 & 3 & 5 & 5 \\
\hline c & 5 & 5 & 5 & 4 & 4 & 5 \\
\hline d & 5 & 5 & 4 & 1 & 2 & 4 \\
\hline $\mathbf{A} \%$ & 51.16 & 58.35 & 62.83 & 87.50 & 75.00 & $62.83^{\mathrm{f}^{*}}$ \\
\hline $\mathrm{Se} \%$ & 61.53 & 64.25 & 71.43 & 94.12 & 86.67 & $71.43^{\mathrm{F}^{*}}$ \\
\hline Sp\% & 45.45 & 50.00 & 50.00 & 44.44 & 44.44 & 50.00 \\
\hline PPV \% & 61.53 & 64.28 & 66.67 & 76.19 & 72.23 & 66.67 \\
\hline NPV \% & 54.54 & 50.00 & 55.56 & 60.00 & 66.67 & 55.56 \\
\hline
\end{tabular}

$\mathrm{a}$ - true positive diagnosis ( 2 with outcome 2$), \mathrm{b}$ - false positive diagnosis ( 2 with outcome 1$)$, c - true negative diagnosis (1 with outcome 1), d - false negative diagnosis (1 with outcome 2), A - accuracy, Se - sensitivity, Sp - specificity, PPV - positive predictive value, NPV - negative predictive value.

f $-57-63$ day vs $43-49$ day at $* \mathrm{P}<0.05$ 


\section{DISCUSSION}

Fertility is among the most important economic traits in small ruminants, especially in goats. The subsistence of millions of people in poorly developed rural regions depends on goat breeding results.

The possible methods for fetal number determination are measurement of blood progesterone concentrations and B-mode ultrasonography. The application of a hormonal test for this purpose depends on the ability for differentiation of circulating progesterone levels during the luteal stage in nonpregnant animals, and during the different gestation stages in pregnant ones, as well as whether it is single or multiple $(10,19)$.

The determination of the fetal number via blood progesterone assay has been mainly carried out in sheep $(3,20,21,22)$ and recently, it is increasingly applied in goats $(4,23)$.

The serum progesterone data obtained in studied goats with different fetal numbers are similar to data reported with various goat breeds $(24,25,26)$. They are opposite to results of Sousa et al. (27), which stated that blood progesterone concentrations were not different in goats with single or multiple pregnancy. The differences in plasma progesterone in sheep carrying one, two or three fetuses are due to the production of higher amounts of progesterone by the multiple placenta apart from the corpora lutea (CL), unlike goats, in which the CL could be the primary source of progesterone for maintenance of pregnancy (28).

The ultrasonography offers a clear advantage for real-time identification of fetal numbers compared to other techniques $(5,6)$. It is the most commonly used method, as it allows for simultaneous determination of fetal number, fetal vitality and gestational age.

In this study, the detection of single or multiple pregnancy through ultrasound imaging indicated that the type of pregnancy had a substantial effect on the accuracy of the method $(\mathrm{P}<0.05)$. For single pregnancies the accuracy was $76.18 \%$, and in twin pregnancies - 72.6\%. Lavoir and Taverne (11) published comparable results. A better accuracy was reported by Dawson et al. (8) - 44\%, 73\% and $67 \%$ on the $35^{\text {th }}$ day up to $83 \%, 89 \%$ and $100 \%$ on the $49^{\text {th }}$ day of gestation, respectively. Amer (29) reported lower percentages in Egyptian dairy goats (accuracy of $45.7 \%$ for single and $54.3 \%$ for twin and triplet pregnancies). The lower accuracy for twin pregnancies is attributed to the higher number of false diagnoses, due to increased fetal moving, counting the same fetus twice or embryonic death occurring in later stage.

The lowest accuracy (21.43\%) was detected in goats carrying three or more offspring in our study. This result was even lower than values reported by Dawson et al. (1) on the $35^{\text {th }}$ day $-67 \%$, but comparable to $25 \%$ accuracy in Saanen goats with 2 or more fetuses investigated by Abdelghafar et al. (30). This unsatisfactory result can be explained by the fact that the precision of the technique depends on the gestational age, the equipment, the probe frequency, study position and the experience of the operator, which has been shown in a previous study (13).

In the period between $21^{\text {st }}-28^{\text {th }}$ days, the accuracy of fetal counting by transrectal ultrasonography was $51.16 \%$ with sensitivity of $58.35 \%$. In one research for determination of fetal numbers in goats, Karen et al. (6) established a total accuracy of $76 \%$ between post mating 24-36 days using the transrectal approach, which is considerably higher than the accuracy in our studies. As the gestational age increases, the possibility for precise determination of fetal numbers using this approach decreases, especially after the $42^{\text {nd }}$ day. The possible causes are the overlapping of ultrasound images of fetuses and impossibility of ultrasonic waves to reach the pregnant uterus (6).

The highest accuracy of $87.50 \%$, sensitivity $94.12 \%$ and positive predictive value $76.19 \%$ of the imaging method were demonstrated between gestational days $43-49^{\text {th }}$ using the transabdominal approach. Medan et al. (7) reported accuracy of $67 \%$ on the $40^{\text {th }}$ day compared to $84 \%$ on the $50^{\text {th }}$ day and $92 \%$ on the $60^{\text {th }}$ day. The cited results confirm the accuracy established by us between the $42^{\text {nd }}$ and the $49^{\text {th }}$ day.

The accuracy of the method could also be influenced by the technique of examination and parturition number, especially in uterine dislocations and examinations performed after the $49^{\text {th }}$ day. In support of this thesis, Karen et al. (31) reported accuracy of $69 \%$ between the $43-56$ day and $71.6 \%$ between $76-87$ gestational days via transabdominal ultrasonography in sheep. In a later research in goats, Karen et al. (6) established a statistically significant difference in accuracy of imaging between young and old animals (93.8\% vs $56.3 \%, \mathrm{P}<0.05)$. This difference is attributed to the possibility for scanning of the entire uterus in young does between the $24-29^{\text {th }}$ day and at the same time; it is much easier to evaluate the number of fetuses than in the advanced stages of pregnancy. The authors concluded that the transrectal approach 
Fetal number in Bulgarian goats: Hormonal and ultrasonographic study

(6-8 MHz) could be utilized for determination of fetal numbers between gestational days 24-36 with accuracy similar to that between 39-51 days and transabdominal approach $(3.5-5 \mathrm{MHz})$ without statistically significant influence of the age of goats.

According to Lavoir and Taverne (11), the most appropriate period for fetal number determination in goats is between the $40^{\text {th }}$ and $70^{\text {th }}$ gestational days using the transabdominal approach. Later studies of Suguna et al. (8) with Indian goat crosses established that transrectal ultrasonography for fetal number determination should be done between the $35^{\text {th }}$ and the $42^{\text {nd }}$ days, whereas transabdominal imaging - between the $42^{\text {nd }}$ and the $49^{\text {th }}$ day.

\section{CONCLUSION}

In conclusion, analysis of our results shows that the fetal numbers in local goats should be determined between gestational days 36-42 by transrectal approach and between days 43-49 with the transabdominal approach. The most appropriate time for determination of fetal number of goats using ultrasonography is between gestational days 42-49.

\section{CONFLICT OF INTEREST STATEMENT}

The authors declared that they have no potential conflict of interest with respect to the authorship and/or publication of this article.

\section{ACKNOWLEDGEMENT}

The authors are grateful to the staff of the goat private farms for their assistance during experiments.

\section{REFERENCES}

1. Dawson, L.J., Sahlu, T., Hart, S.P., Detweiler, G., Gipson, T.A., Theh, T.H., Henry, G.A., Bahr, R.J. (1994). Determination of fetal numbers in Alpine does by real time ultrasonography. Small Rumin Res. 14, 225-231. https://doi.org/10.1016/0921-4488(94)90045-0

2. Erdogan, G. (2012). Ultrasonic assessment during pregnancy in goats - a review. Reprod Dom Anim. 47, 157-163.

https://doi.org/10.1111/j.1439-0531.2011.01873.x PMid:21771111

3. Yotov, S. (2007). Diagnostics of early pregnancy and determination of fetal sex and number in sheep. $\mathrm{PhD}$ thesis, Stara Zagora. [in Bulgarian]
4. Capezzuto, A., Chelini, M.O.M., Felippe, E.C.G., Olivera, C.A. (2008). Correlation between serum and fecal concentration of reproductive steroids throughout gestation in goats. Anim Reprod Sci. 103, 78-86. https://doi.org/10.1016/j.anireprosci.2006.11.001 PMid:17156948

5. Medan, M.S., Abd El-Aty, A.M. (2010). Advances in ultrasonography and its application in domestic ruminants and other farm animals ${ }^{6}$ reproduction. J Adv Res. 1, 123-128. https://doi.org/10.1016/j.jare.2010.03.003

6. Karen, A., Samir, H., Ashmawy, T., El-Sayed, M. (2014). Accuracy of B-mode ultrasonography for diagnosing pregnancy and determination of fetal numbers in different breeds of goats. Anim Reprod Sci. 147, 25-31.

https://doi.org/10.1016/j.anireprosci.2014.03.014 PMid:24746553

7. Medan, M., Watanabe, G., Absy, G., Sasaki, K., Sharawy, S., Taya, K. (2004). Early pregnancy diagnosis by means of ultrasonography as a method of improving reproductive efficiency in goats. J Reprod Dev. 50, 391-397. https://doi.org/10.1262/jrd.50.391 PMid:15329470

8. Suguna, K., Mehrotra, S., Agarwal, S.K., Hoque, M., Singh, S.K., Shanker, U., Sarath, T. (2008). Early pregnancy diagnosis and embryonic and fetal development using real time B mode ultrasound in goats. Small Rumin Res. 80, 80-86. https://doi.org/10.1016/j.smallrumres.2008.10.002

9. Yotov, S. (2011). Determination of fetal numbers and sex. In: S. Yotov (Ed.), Application of B-mode echography in sheep reproduction (pp. 78-88). Stara Zagora: Kota Publishing House. [in Bulgarian]

10. Dawson, L. J. (2002). Pregnancy diagnosis in goats. Proceedings of the 17th Annual Goat Field Day (pp. 41-44), Langston University, Langston.

11. Lavoir, M.C., Taverne, M.A.M. (1989). The diagnosis of pregnancy and pseudo pregnancy, and the determination of foetal numbers of goats, by means of real time ultrasound scanning. In: M. A. M. Taverne, A. H. Willemse (Eds.), Diagnostic ultrasound and animal reproduction (pp. 89-96). Dordrecht: Kluwer Academic Publisher. https://doi.org/10.1007/978-94-017-1249-1_8

12. Vinoles-Gil, C., Gonzales-Bulnes, A., Martin, G.B., Zlatar, F.S., Sale, S. (2010). Sheep and goats. In: L. Des Coteaux, J. Colloton, G. Gnemmi(Eds.), Ruminantand camelid reproductive ultrasonography (pp. 181-210). Hong Kong: Willey- Blackwell.

13. Karen, A., Kovacsi, P., Beckers, J.F., Szenci, O. (2001). Pregnancy diagnosis in sheep: review of the most practical methods. Acta Vet Brno 70, 115-126. https://doi.org/10.2754/avb200170020115 
14. Koker, A., Ince, D., Sezik, M. (2012). The accuracy of transvaginal ultrasonography for early pregnancy diagnosis in Saanen goats: a pilot study. Small Rumin. Res. 105, 277-281.

https://doi.org/10.1016/j.smallrumres.2012.02.013

15. Abdelghafar, R.M., Bakhiet, A.O., Ahmed, B.H. (2007). B-mode real-time ultrasonography for pregnancy diagnosis and fetal number in Saanen goats. J Anim Vet Adv. 6, 702-705.

16. Padilla-Rivas, G.R., Sohnrey, B., Holtz, W. (2005). Early pregnancy detection by real time ultrasonography in Boer goats. Small Rumin Res. 58, 87-92.

https://doi.org/10.1016/j.smallrumres.2004.09.004

17. Gearhart, M.A., Wingfield, W.E., Knight, A.P., Smith, J.A, Dorgatz, D.A., Boon, J.A., Stokes, C.A. (1988). Real-time ultrasonography for determining pregnancy status and viable fetal numbers in ewes. Theriogenology 30, 323-337.

https://doi.org/10.1016/0093-691X(88)90180-X

18. Martin, S. W., Meek, A. H., Willeberg, P. (1987). Measurement of disease frequency and production. In: S. W. Martin, A. H. Meek, P. Willeberg (Eds.), Veterinary epidemiology: principles and methods (pp. 63-71). USA: Iowa State University Press.

19. Gonzalez, F., Cabrera, F., Batista, M., Rodriguez, N., Alamo, D., Sulon, J., Beckers, J.F. (2004). A comparison of diagnosis of pregnancy in the goat via transrectal ultrasound scanning, progesterone and pregnancy associated glycoprotein assays. Theriogenology 62, 1108-1115.

https://doi.org/10.1016/j.theriogenology.2003.12.009 PMid:15289050

20. Kulcsár, M., Dankó, G., Magdy, H.G., Reiczigel, J., Forgach, T., Proháczik, A., Delavaud, C., Magyar, K., Chilliard, Y., Solti, L., Huszenicza, G. (2006). Pregnancy stage and number of fetuses may influence maternal plasma leptin in ewes. Acta Vet Hung. 54, 221-234.

https://doi.org/10.1556/AVet.54.2006.2.9

PMid:16841760

21. Muller, T., Schibert, H., Schwab, M. (2003). Early prediction of fetal number in sheep based on peripheral plasma progesterone concentration and season of year. Vet Rec. 1, 137-138.

https://doi.org/10.1136/vr.152.5.137

22. See, K., Bailer, A.J., Behnke, E.J., Baker, R.S., Clark, K.E., Russell, P.T. (2007). Predicting pregnancy status and fetal number in time-dated pregnant ewes using serum progesterone and ultrasound. Res J Anim Sci. 1, 65-71.
23. Boscos, C.M., Samartzi, F.C., Lymberopoulos, A.G., Stefanakis, A., Belibasaki, S. (2003). Assessment of progesterone concentration using enzyme immunoassay for early pregnancy diagnosis in sheep and goats. Reprod Dom Anim. 38, 170-174. https://doi.org/10.1046/j.1439-0531.2003.00407.x

24. Chentouf, M., Bister, J.L., Boulanouar, B. (2011). Reproduction characteristics of North Moroccan indigenous goats. Small Rumin Res. 98, 185-188. https://doi.org/10.1016/j.smallrumres.2011.03.037

25. Gaafar, K.M., Gabr, M.K., Teleb, D.F. (2005). The hormonal profile during the estrous cycle and gestation in Damascus goats. Small Rumin Res. 57, 85-93.

https://doi.org/10.1016/j.smallrumres.2004.07.009

26. Khan, J.R., Ludri, R.S. (2002). Hormonal profiles during periparturient period in single and twin fetus bearing goats. Asian Aust J Anim Sci. 15, 346-351. https://doi.org/10.5713/ajas.2002.346

27. Sousa, N.M., Garbayo, J.M., Figueiredo, J.R., Sulon, J., Goncalves, P.B.D., Beckers, J.F. (1999). Pregnancy associated glycoprotein and progesterone profiles during pregnancy and postpartum in native goats from the north-east of Brazil. Small Rumin Res. 32, 137-147. https://doi.org/10.1016/S0921-4488(98)00171-0

28. Gordon, I. (1997). Pregnancy testing in sheep. In: I. Gordon (Ed.), Controlled reproduction in sheep and goats (pp. 241-259). New York: CABI Publishing. PMid:9033527

29. Amer, H.A. (2010). Ultrasonographic assessment of early pregnancy diagnosis, fetometry and sex determination in goats. Anim Reprod Sci. 117, 226-231. https://doi.org/10.1016/j.anireprosci.2009.05.015 PMid:19535206

30. Abdelghafar, R. M., Ibrahim, R. M., Abdelharimi, S. M., Ahmed, B. H. (2010). Sensitivity and specificity of real-time ultrasonography for pregnancy diagnosis and litter size in Saanen goats (Capra Hircus). Proceedings of the 14th Sci. Cong. Fac. Vet. Med. Assiut Univ. November 30 - December 02, (pp. 391402), Egypt.

31. Karen, A., Szabados, K., Reiczigel, J., Beckers, J.F., Szenci, O. (2004). Accuracy of transrectal ultrasonography for determination of pregnancy in sheep: effect of fasting and handling of the animals. Theriogenology 61, 1291-1298. https://doi.org/10.1016/j.theriogenology.2003.07.018 PMid:15036963 